\title{
Dosimetric Properties of the Newly Developed LiF:Mg,Cu,Si TL Material
}

\author{
M. S. Rahman ${ }^{1 *}$, J. I. Lee $^{2}$, J .L. Kim², and G. Cho ${ }^{3}$ \\ ${ }^{1}$ Health Physics Division, Atomic Energy Centre, 4 Kazi Nazrul Islam Avenue, Ramna, Dhaka-1000, \\ Bangladesh \\ ${ }^{2}$ Health Physics Department, Korea Atomic Energy Research Institute, P.O. Box 105, Yuseong, \\ Daejeon, Korea \\ ${ }^{3}$ Dept. of Nuclear and Quantum Engineering, Korea Advanced Institute of Science and Technology, \\ Daejeon, Korea
}

Received 25 September 2012, accepted in final revised form 26 December 2012

\begin{abstract}
The dosimetric properties of the newly developed thermoluminescence (TL) material ( $\mathrm{LiF}: \mathrm{Mg}, \mathrm{Cu}, \mathrm{Si}$ ) at Korea Atomic Energy Research Institute (KAERI) were investigated. The energy response of the detector was performed for photon energies from 20 to $662 \mathrm{keV}$. The dose response for this TL material ( $\mathrm{LiF}: \mathrm{Mg}, \mathrm{Cu}, \mathrm{Si}$ ) was linear up to $10 \mathrm{~Gy}$ and a sublinear response was observed for higher doses. The reusability of this newly developed TL detector sufficiently satisfied IEC standards. Detection threshold of $\mathrm{LiF}: \mathrm{Mg}, \mathrm{Cu}, \mathrm{Si} \mathrm{TL}$ material was investigated and found to be 930 nGy by Harshaw 4500 TLD reader.
\end{abstract}

Keywords: Dosimetry; TL; TLD; Dose.

(C) 2013 JSR Publications. ISSN: 2070-0237 (Print); 2070-0245 (Online). All rights reserved.

doi: http://dx.doi.org/10.3329/jsr.v5i1.11935 J. Sci. Res. 5 (1), 25-31 (2013)

\section{Introduction}

Although LiF:Mg,Ti as TLD-100 has proven to be a useful phosphor for thermoluminescence dosimetry, and $\mathrm{LiF}: \mathrm{Mg}, \mathrm{Cu}, \mathrm{P}$ has become a popular TL dosimeter in routine applications of personal, environmental and clinical dosimetry [1]. However, the integrated processes of sintering and microstructure development in a crystalline compound are so complex that even after 50 years of research. Over this time, research on luminescence micro and nanocrystalline materials has been greatly accelerated by the advances in the ability to manipulate structures at molecular or atomic level [2]. The search for the ideal phosphor will continue as long as there is a need for improvement.

The main advantages of LiF: $\mathrm{Mg}, \mathrm{Cu}, \mathrm{P}$ are the high sensitivity, good tissue equivalence, almost flat energy response, low fading rate, linear dose response, and good stability at ambient temperatures and the shorter annealing procedures [3]. The two main demerits are

\footnotetext{
* Corresponding author: msrahman1974@yahoo.com
} 
the thermal loss of TL sensitivity in $\mathrm{LiF}: \mathrm{Mg}, \mathrm{Cu}, \mathrm{P}$ annealed at temperature above $240{ }^{\circ} \mathrm{C}$, and the relatively high residual signal [4].

$\mathrm{LiF}$ doped with $\mathrm{Mg}, \mathrm{Cu}$ and $\mathrm{Si}$ impurities was first introduced in Japan [5]. At that time, the relative thermoluminescence intensity of this material was only 7 times as high as that of TLD-100, much less than that of LiF:Mg,Cu,P. Last few years, the main features of $\mathrm{LiF}: \mathrm{Mg}, \mathrm{Cu}, \mathrm{Na}, \mathrm{Si}$ as KLT-300 (KAERI LiF:Mg,Cu,Na,Si TL detector) had been improved significantly [6], which possesses high sensitivity and good reusability. But the main drawback of the KLT-300 is that the glow curve shape and TL sensitivity decreased significantly when annealed at temperatures above $245^{\circ} \mathrm{C}$. So there is a need to develop a new TL material with the useful properties of $\mathrm{LiF}: \mathrm{Mg}, \mathrm{Cu}, \mathrm{P}$ but having a lower residual signal and a better stability to heat treatment. In this paper, some dosimetric properties of the newly developed sintered pellet-type $\mathrm{LiF}: \mathrm{Mg}, \mathrm{Cu}, \mathrm{Si} \mathrm{TL}$ detector such as energy response, dose response, reusability and detection threshold has been reported.

\section{Materials and Methods}

\subsection{Sample preparation}

With $\mathrm{LiF}$ powder, $0.2 \mathrm{~mol} \%$ of $\mathrm{MgSO}_{4} .7 \mathrm{H}_{2} \mathrm{O}, 0.05 \mathrm{~mol} \%$ of $\mathrm{CuSO}_{4} .5 \mathrm{H}_{2} \mathrm{O}$, and 0.9 mol $\%$ of $\mathrm{SiO}_{2}$ were mixed in distilled water by a magnetic stirrer and then dried at $150{ }^{\circ} \mathrm{C}$. For the activation process of the $\mathrm{LiF}$ crystals, the mixture of $\mathrm{LiF}$ and 3 dopants as mentioned above were heated in an electric furnace at temperature well below the melting point of $\mathrm{LiF}$ for $30 \mathrm{~min}$ without nitrogen gas flow. A pellet-type, with a size of $4.5 \mathrm{~mm}$ in diameter and $0.8 \mathrm{~mm}$ in thickness were fabricated using a mechanical press after pulverization. Annealing temperature and time are used to produce the lowest intrinsic background and to obtain the highest efficiency [7]. The details of the preparation procedure can be found elsewhere [8].

\section{Dosimetric Properties}

\subsection{Energy response}

For the determination of the energy response of this new TL detector, 6 groups, each group containing $5 \mathrm{TL}$ detectors were prepared. The photon irradiations for each group were performed at effective photon energies of 20,35, 53, 73, 118 and $662 \mathrm{keV}$ using an $\mathrm{X}$-ray generator $(20-118 \mathrm{keV})$ and Cs-137 source $(662 \mathrm{keV})$ with $5 \mathrm{~mm}$ of PMMA (polymethyl methacrylate) as a build-up material at Korea Atomic Energy Research Institute (KAERI). The TL measurement was carried out using a Harshaw 4500 TLD reader.

\subsection{Dose response}

To investigate the dose response of the TL detector, 10 groups, each group containing 5 TL detectors were prepared and then the TL detectors for each group were exposed with a dose of $10^{-5}, 10^{-4}, 10^{-3}, 10^{-2}, 10^{-1}, 1.0,10.0,20.0,30.0$ and 50.0 Gy by using Cs-137 source with $5 \mathrm{~mm}$ of PMMA (polymethyl methacrylate) as a build-up material at KAERI. During 
TL measurement, to eliminate the low temperatures peaks, the samples were preheated at $135{ }^{\circ} \mathrm{C}$ for $10 \mathrm{~s}$ and then TL signals were recorded by increasing the temperature up to $260{ }^{\circ} \mathrm{C}$ with a heating rate of $10^{\circ} \mathrm{C} / \mathrm{s}$ using Harshaw $4500 \mathrm{TLD}$ reader.

\subsection{Reusability}

The reusability study of the newly developed $\mathrm{LiF}: \mathrm{Mg}, \mathrm{Cu}, \mathrm{Si}$ TL detector is carried out following the procedure of IEC 1066 [9]. For this study, 10 detectors were prepared and irradiated by Cs-137 source with a dose of $10 \mathrm{mGy}$. This experiment was repeated 10 times in the same manner. The TL signals were measured following the same temperature profile as mentioned above for the case of dose response experiment.

\subsection{Detection threshold}

According to IEC 1066 [9], the detection threshold is defined as detection threshold $=t_{\mathrm{n}} \cdot \sigma$, where $t_{\mathrm{n}}$ is the student's $t$ distribution for $n-1$ degrees of freedom ( $\mathrm{n}$ number of dosemeters used for the test) and $\sigma$ is the standard deviation of the evaluated values for all the $n$ dosemeters. To determine the detection threshold of this new TL detector, ten unirradiated samples were prepared, and then the TL signals were measured following the same temperature profile as mentioned above for the case of dose response experiment.

\section{Results and Discussion}

\subsection{Energy response}

Fig. 1 shows the relative energy response normalized to $662 \mathrm{keV} \gamma$-ray (Cs-137) of the new TL detector (LiF:Mg,Cu,Si), MCP-N (LiF:Mg,Cu,P) and TLD-100 (LiF:Mg,Ti). The experimental results for the MCP-N and KLT-300 were obtained from the papers Budzanowski et al. [10] and Lee et al. [11]. The energy response of the new TL detector is similar to MCP-N and the maximum response of 1.0387 at $35 \mathrm{keV}$ and the minimum response of 0.791 at $117 \mathrm{keV}$ are observed. The response of this TL detector is lower than that of KLT-300 in the range of $72-249 \mathrm{keV}$.

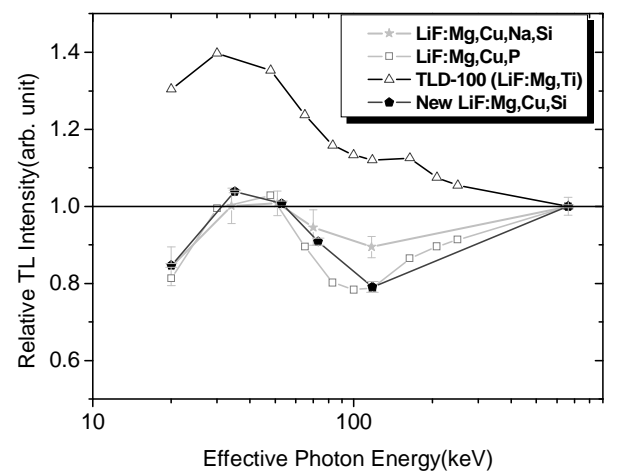

Fig. 1. Relative energy response of $\mathrm{LiF}: \mathrm{Mg}, \mathrm{Cu}, \mathrm{Si} \mathrm{TL}$ detector. 


\subsection{Dose response}

The linearity of the TL phosphor to radiation dose is one of the important properties for a TL detector. Fig. 2 (a) illustrates dose response for $\mathrm{LiF}: \mathrm{Mg}, \mathrm{Cu}, \mathrm{Si} \mathrm{TL}$ detector as a function of absorbed dose. It can be seen that the response is linear from $10^{-4}$ to $10 \mathrm{~Gy}$. In the range above $10 \mathrm{~Gy}$, the response increases sub-linearly with dose. This is consistent with the results of Bacci et al. [12] for $\mathrm{LiF} ; \mathrm{Mg}, \mathrm{Cu}, \mathrm{P}$ TL detector, $\mathrm{K}$. Tang et al. [13] and J.I. Lee et al. [11] for LiF:Mg, Cu,Na,Si TL detector. For more clarity, the normalized dose response function is represented in Fig. 2 (b).

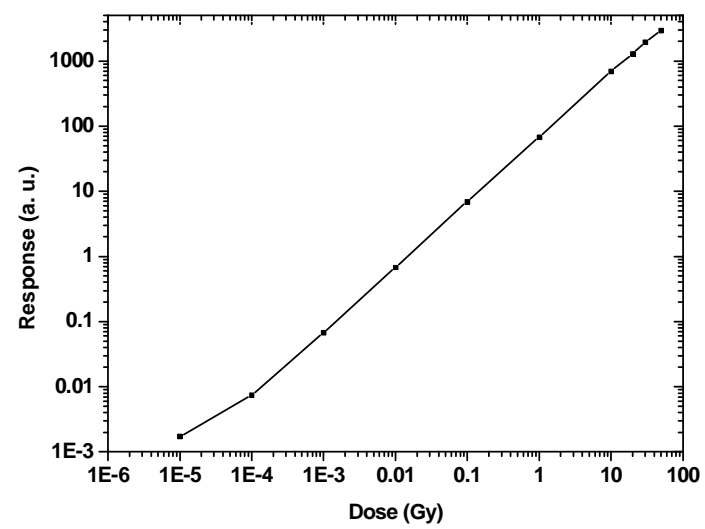

Fig. 2 (a). Dose response of $\mathrm{LiF}: \mathrm{Mg}, \mathrm{Cu}, \mathrm{Si} \mathrm{TL}$ detector as a function of absorbed dose.

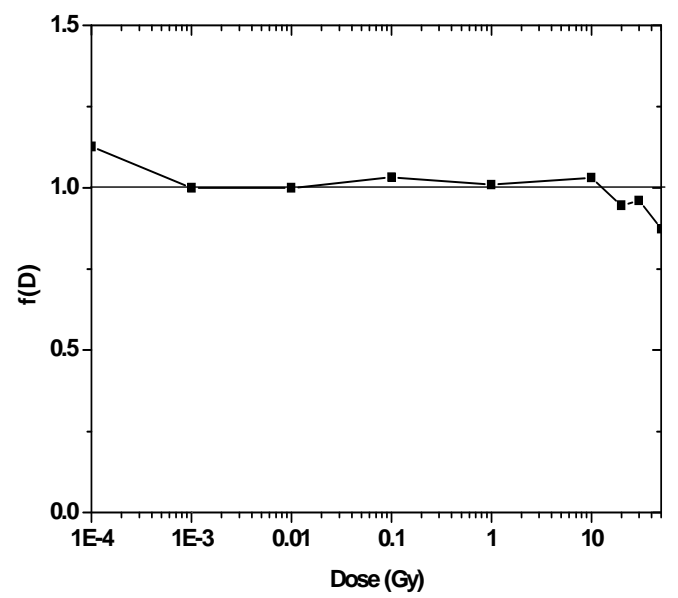

Fig. 2 (b). Relative dose response function of $\mathrm{LiF}: \mathrm{Mg}, \mathrm{Cu}, \mathrm{Si} \mathrm{TL}$ detector. 


\subsection{Reusability}

The coefficient of variation (CV) of measured TL signals for each detector and for all the 09 detectors collectively are shown in Table 1 . The CV for each detector and for all 09 detectors collectively did not exceed 0.021 and 0.0039 respectively. According to IEC 1066 requirement [9], the CV shall not exceed 0.075 . So, the reusability of the new TL detector adequately satisfied the IEC standards. Fig. 3 depicts the variation of the average value of TL signals of this TL detector with the number of reused cycles. The extent of radiation damage determines the frequency with which re-calibration is necessary in high

Table 1. Reusability of new LiF:Mg,Cu,Si TL detectors.

\begin{tabular}{cc}
\hline Each detector separately & \\
\hline Dosimeter ID & Coefficient of variation \\
\hline 01 & 0.01500 \\
02 & 0.00729 \\
03 & 0.01535 \\
04 & 0.00914 \\
05 & 0.00587 \\
06 & 0.01121 \\
07 & 0.00861 \\
08 & 0.01157 \\
09 & 0.02098 \\
All dosimeter collectively & 0.003878 \\
\hline
\end{tabular}

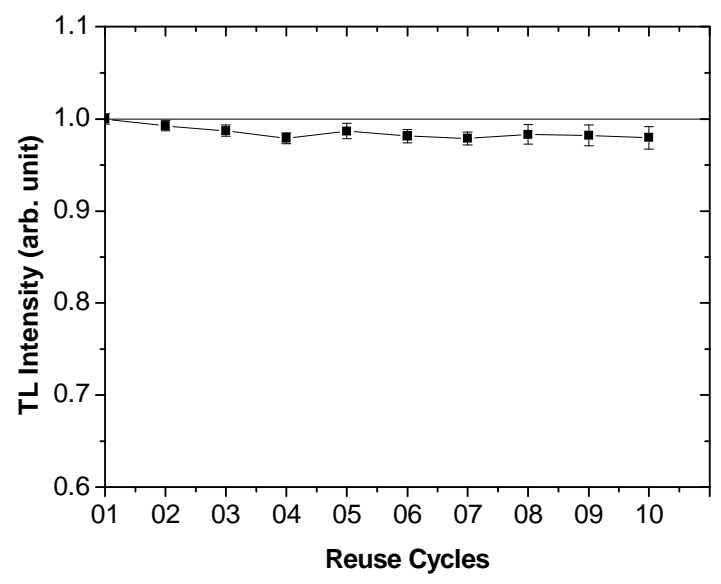

Fig. 3. Reusability of LiF:Mg, $\mathrm{Cu}, \mathrm{Si} \mathrm{TL}$ detectors. 
precision dose measurements and is an important factor in the ease of applicability of LiFTLD. From Fig. 3, it is observed that about $2 \%$ sensitivity decreases after 10 repeated use of the same $\mathrm{LiF}: \mathrm{Mg}, \mathrm{Cu}, \mathrm{Si} \mathrm{TL}$ material due to radiation damage. If frequency of use of this materials is three months (which is common in Bangladesh for routine application) and $5 \%$ reduction of intensity is permitted, then it is recommended to re-calibrate the LiF:Mg,Cu,Si TL detector every 7 years interval for accurate dose measurement. Table 2 depicts the comparison of important dosimetric properties of $\mathrm{LiF}: \mathrm{Mg}, \mathrm{Cu}, \mathrm{Si}$ and TLD-100 (LiF:Mg,Ti).

Table 2. Comparison of dosimetric properties of LiF:Mg,Cu,Si with LiF:Mg,Ti (TLD-100).

\begin{tabular}{|c|c|c|}
\hline Dosimetric properties & $\mathrm{LiF}: \mathrm{Mg}, \mathrm{Cu}, \mathrm{Si}$ & TLD-100 (LiF:Mg, Ti) \\
\hline Sensitivity & 20 & 1 \\
\hline Signal to noise ratio $(\mathrm{S} / \mathrm{N})$ & $0.04 \%$ & $\begin{array}{l}\text { Three orders of magnitude higher } \\
\text { than that of } \mathrm{LiF}: \mathrm{Mg}, \mathrm{Cu}, \mathrm{Si}\end{array}$ \\
\hline $\begin{array}{l}\text { Use for environmental } \\
\text { monitoring }\end{array}$ & Possible & Not possible \\
\hline Annealing temperature & $\begin{array}{l}300^{\circ} \mathrm{C} / 260^{\circ} \mathrm{C} \text { for } 10 \mathrm{~min} \\
\text { before irradiation }\end{array}$ & $\begin{array}{l}400^{\circ} \mathrm{C} \text { for } 1 \mathrm{~h} \text { and } 100{ }^{\circ} \mathrm{C} \text { for } 2 \mathrm{~h} \\
\text { before irradiation }\end{array}$ \\
\hline Thermal stability & High thermal stability & Thermal instability \\
\hline Response below $100 \mathrm{keV}$ & $\begin{array}{l}\text { Lower response observed } \\
\text { except } 30-50 \mathrm{keV}\end{array}$ & $\begin{array}{l}\text { Over response observed due to peaks } \\
4 \text { and } 5 \text {. }\end{array}$ \\
\hline
\end{tabular}

\subsection{Detection threshold}

Detection threshold of the new TL detector was investigated and found to be $930 \mathrm{nGy}$ by Harshaw 4500 TLD reader.

\section{Conclusion}

The energy response of $\mathrm{LiF}: \mathrm{Mg}, \mathrm{Cu}, \mathrm{Si} \mathrm{TL}$ detector is very similar with $\mathrm{MCP}-\mathrm{N}$ (LiF: $\mathrm{Mg}, \mathrm{Cu}, \mathrm{P})$. The dose response for this TL material $(\mathrm{LiF}: \mathrm{Mg}, \mathrm{Cu}, \mathrm{Si}$ ) is linear up to 10 Gy and a sub-linear response is observed for higher doses. This newly developed TL detector shows acceptable reusability.

\section{Acknowledgements}

This study was carried out under the national long term and intermediate term project of nuclear energy development funded by the Ministry of Science and Technology, Korea.

\section{References}

1. C. R. Hirning, Radiat. Prot. Dosim. 66, 63 (1996). http://dx.doi.org/10.1093/oxfordjournals.rpd.a031782 
2. T. Rivera, J. Roman, J. Azorín, R. Sosa, J. Guzmán, A. K. Serrano, M. García and G. Alarcón, Appl. Radiat. and Isot. 68, 623 (2010). http://dx.doi.org/10.1016/j.apradiso.2009.09.033

3. J. C. Saez-Vergara, Radiat. Prot. Dosim. 92, 83 (2000). http://dx.doi.org/10.1093/oxfordjournals.rpd.a033289

4. A. Horowitz and Y. S. Horowitz, Radiat. Prot. Dosim. 40, 265 (1992).

5. T. Nakajima, Y. Murayama, T. Matsuzawa and A. Koyano, Nucl. Instrum. Methods 157, 155 (1978). http://dx.doi.org/10.1016/0029-554X(78)90601-8

6. J. I. Lee, J. L. Kim, S. Y. Chang, K. S. Chung and H. S. Choe, Radiat. Prot. Dosim. 108, 79 ( 2004). http://dx.doi.org/10.1093/rpd/nch001

7. T. Rivera, Synthesis and Thermoluminescent Characterization of Ceramics Materials (INTECH Publisher, August 2011). http://www.intechopen.com/books

8. J. I. Lee, J. L. Kim, M. S. Rahman, S. Y. Chang, K. S. Chung, and H. S. Choe, Radiat. Prot. Dosim. 125, 229 (2007). http://dx.doi.org/10.1093/rpd/ncl122

9. IEC (International Electrotechnical Commission) 1066 International Standard (Thermoluminescence dosimetry systems for personal and environmental monitoring, 1991).

10. M. Budzanowski, J. L. Kim, Y. M. Nam, S. Y. Chang, P. Bilski, P. Olko, Radiat. Meas. 33, 537(2001). http://dx.doi.org/10.1016/S1350-4487(01)00054-3

11. J. I. Lee, J. L. Kim, S. Y. Chang, K.S. Chung and H. S. Choe, Radiat. Meas. 38, 439 ( 2004). http://dx.doi.org/10.1016/j.radmeas.2003.12.020

12. C. Bacci, L. D'Angelo, C. Furetta and S. Giancola, Radiat. Prot. Dosim. 47 (1-4), 215 (1993).

13. K. Tang, H. Zhu, W. Shen, B. Liu, Radiat. Prot. Dosim. 100, 239 (2002). http://dx.doi.org/10.1093/oxfordjournals.rpd.a005855 